\title{
Editorial
}

\section{Solar Cells: From Sunlight into Electricity}

\author{
Serap Günes, ${ }^{1}$ M. S. A. Abdel-Mottaleb, ${ }^{2}$ Harald Hoppe, ${ }^{3}$ and Daniel Ayuk Mbi Egbe ${ }^{4}$ \\ ${ }^{1}$ Department of Physics, Faculty of Arts and Science, Yildiz Technical University, Davutpasa Campus, Esenler, 34210 Istanbul, Turkey \\ ${ }^{2}$ Nano-Photochemistry and Solar Chemistry Lab, Department of Chemistry, Faculty of Science, Ain Shams University, Abbassia, \\ Cairo 11566, Egypt \\ ${ }^{3}$ Institute of Physics, Technische Universität Ilmenau, 98693 Ilmenau, Germany \\ ${ }^{4}$ Linz Institute for Organic Solar Cells, Johannes Kepler University of Linz, Altenberger Strasse, 4040 Linz, Austria \\ Correspondence should be addressed to Serap Günes; sgunes@yildiz.edu.tr
}

Received 17 March 2015; Accepted 17 March 2015

Copyright (C) 2015 Serap Günes et al. This is an open access article distributed under the Creative Commons Attribution License, which permits unrestricted use, distribution, and reproduction in any medium, provided the original work is properly cited.

Presently, the major part of the global energy need is covered by fossil fuels such as coal, gas, oil, and nuclear power plants. The conventional methods lead to serious environmental problems and especially the ever-rising demand for these energy carriers in conjunction with the expected oil depletion can be counted as the world's most important energy problem. Also, the uneven distribution of the oil around the whole world threatens the world peace.

Alternative methods which could compete with the conventional energy production have been approached for saving the environment, economy, and the world peace. Solar light to electricity via photovoltaics has been promising alternatives to conventional methods. As solar cells are classified into three groups, first, second, and third generation, the first generation which is made of crystalline silicon remains the commercially most predominant solar cell technology. The second-generation solar cells are the thin film solar cells and include inorganic semiconductors such as CdTe, CdS, and CIGS which are also commercially available. Although the production price of these two technologies decreased considerably over the last years, the first-generation solar cells are still relatively expensive and production procedures include cost and energy intensive routes. This stands as a major drawback in their widespread use, especially in household type applications. The third generation includes use of organic and organometallic materials and is seen as emerging technology. Low cost, light weight, and easy integration to flexible applications make this emerging technology worthy of being investigated further. However, their efficiencies are still low as compared to their inorganic counterparts and therefore they are considered to be in the development stage and are not yet widely commercially available. Thus, overall many photovoltaic approaches have been studied and efforts are currently continuing in order to provide more cost and energy efficient solar energy solutions.

This special issue addresses the ongoing efforts towards new results in materials science and technology related to different types of solar cells such as organic, inorganic, and dye sensitized solar cells. This issue contains papers on various aspects of different generations of solar cells. These aspects can be categorized as follows: (1) investigation of Sithin films and improved performance of silicon solar cells; (2) investigations of $\mathrm{ZnO}: \mathrm{Al}$ layers for CIGS solar cells; (3) theoretical and experimental studies on PV modules, solar concentrators, and dye sensitized solar cells; (4) further development of various types of hybrid and organic solar cells.

\section{Acknowledgment}

We owe special thanks to all authors who contribute their interesting work to this timely issue. We hope that the readers enjoy this special issue.

Serap Günes

M. S. A. Abdel-Mottaleb

Harald Hoppe

Daniel Ayuk Mbi Egbe 

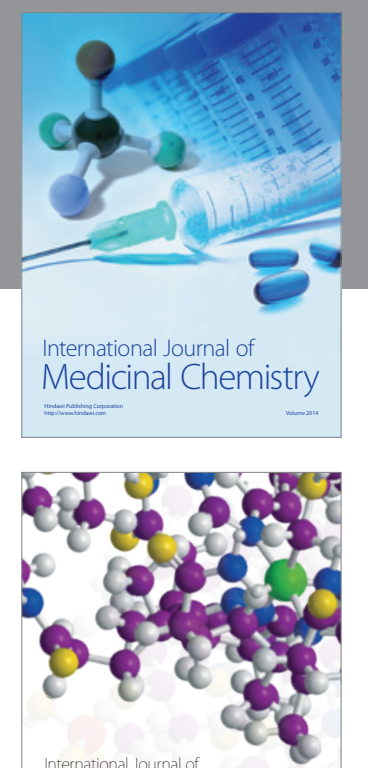

\section{Carbohydrate} Chemistry

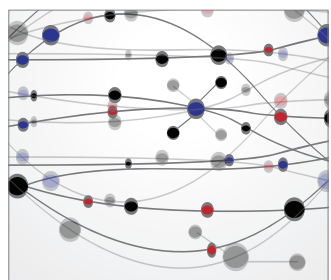

The Scientific World Journal
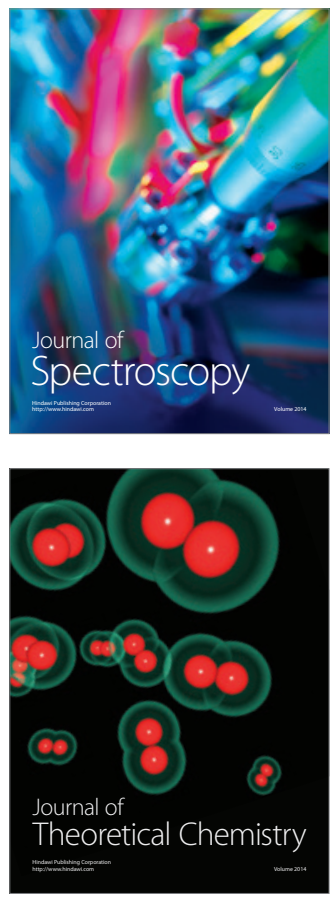
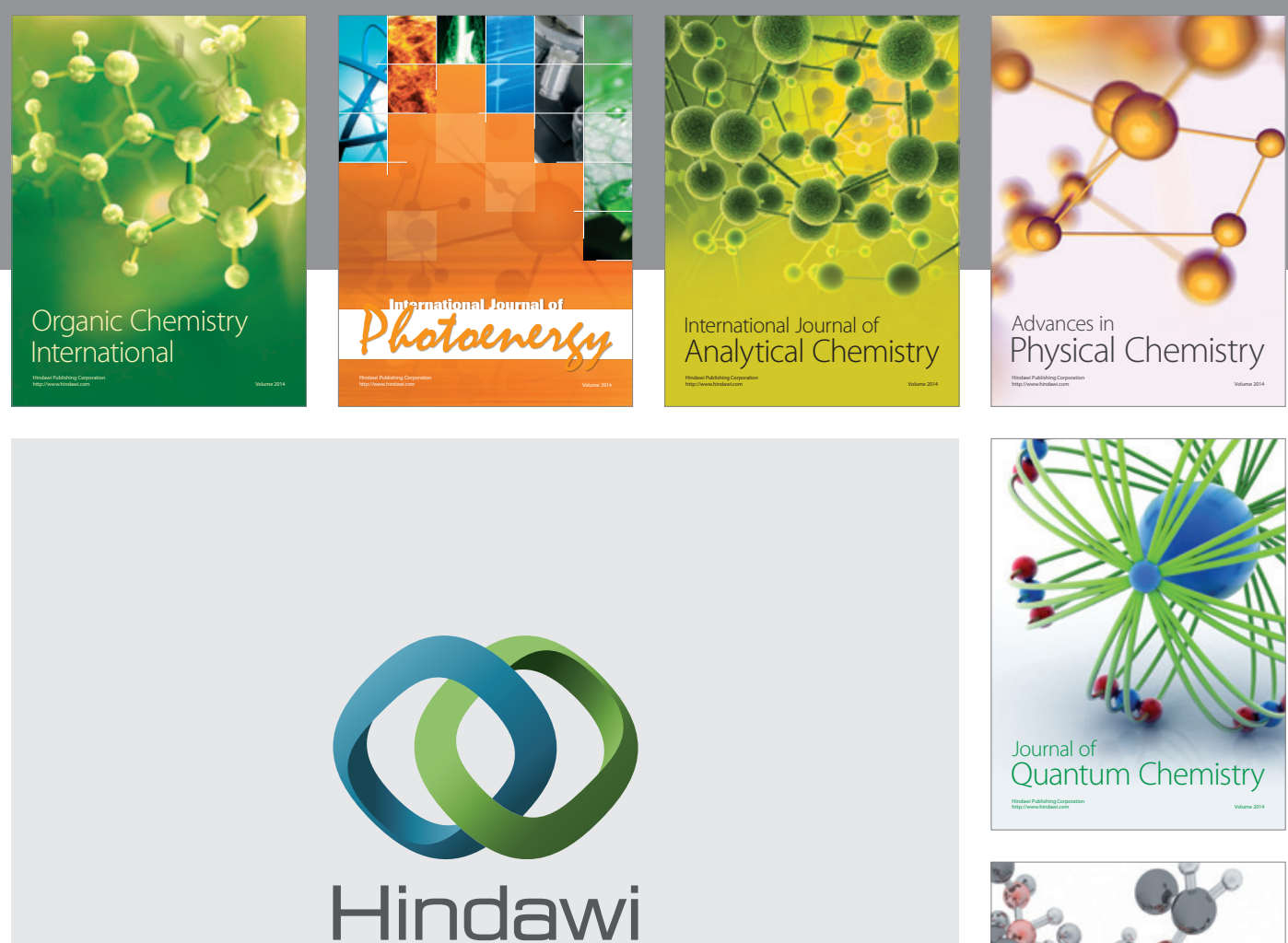

Submit your manuscripts at

http://www.hindawi.com

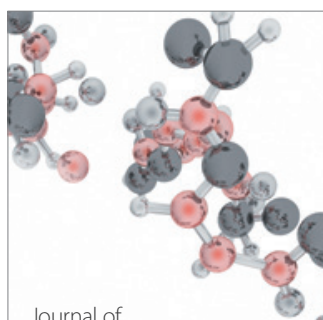

Analytical Methods

in Chemistry

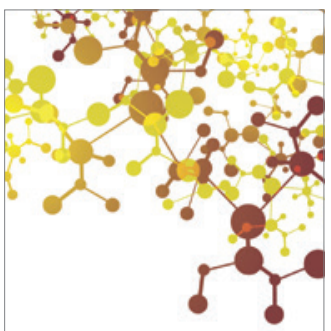

Journal of

Applied Chemistry

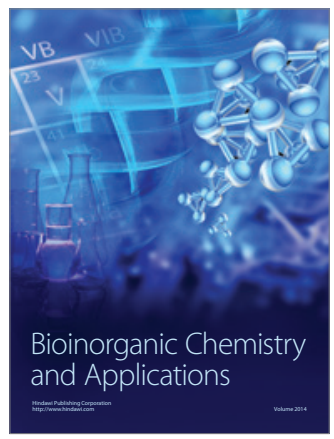

Inorganic Chemistry
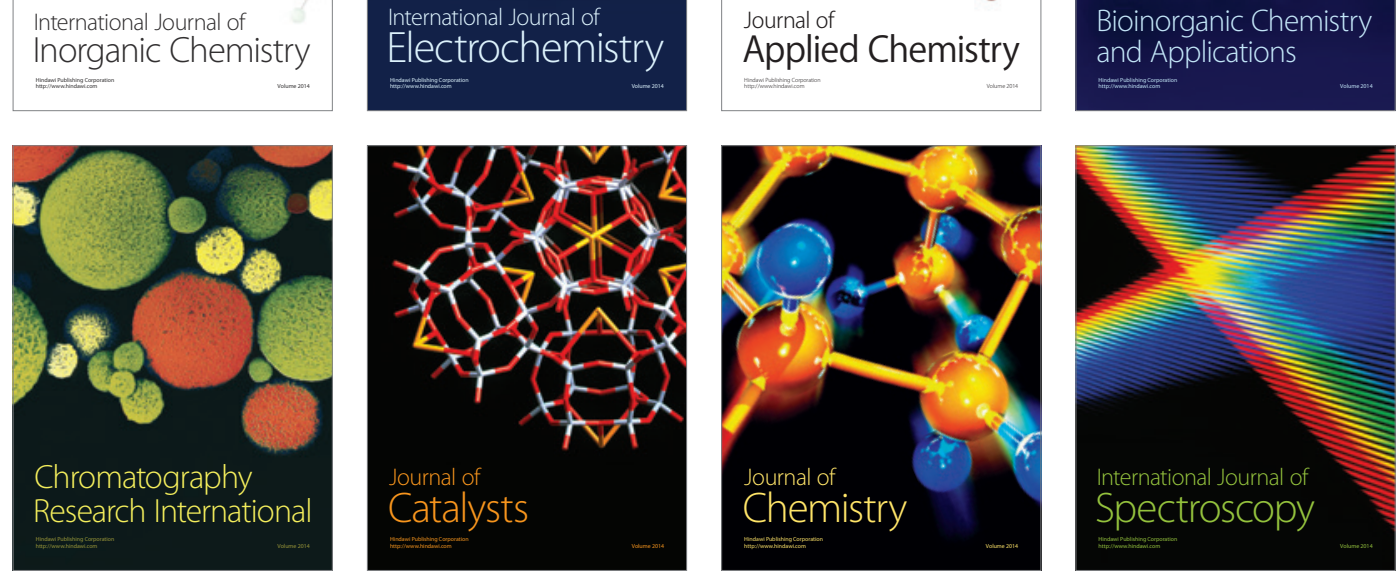